\title{
The Management of the Enrichment Curriculum in Public Madrasah Aliyah 1 Unggulan Tulungagung Indonesia
}

\author{
Abdul Manab ${ }^{1}$ \\ ${ }^{1}$ Islamic State Institute Tulungagung, Indonesia \\ Correspondence: Abdul Manab, Islamic State Institute Tulungagung, Jl. Mayor Sujadi Timur No. 46, \\ Tulungagung, Indonesia. E-mail: abdulmanab_stain@yahoo.co.id
}

Received: November 26, 2014

doi: $10.5539 /$ ies.v8n5p 172

\author{
Accepted: January 6, 2015 Online Published: April 28, 2015
}

URL: http://dx.doi.org/10.5539/ies.v8n5p172

\begin{abstract}
The objective of this research is to examine: 1) the background in doing the curriculum enrichment; 2) the stages in managing the curriculum enrichment, and 3) the implications and the management of the curriculum enrichment. It is qualitative and naturalistic in nature with a case-study approach and, an interpretative analysis was made on the empirical data using a reflective-interpretatif method and a theory of analysis of spiral data. The results showed that 1) the curriculum enrichment was made by an educational institution, related to the excellence program, and its implementation was based on the academic experiences and tried to apply ideas of modernity; 2) teachers were very dominant in doing the changes and also in making the analysis, in determining the indicators of the curriculum materials for MAN I Unggulan Tulungagung, and anything was are based on the decision of the educational institution as the implementing manager; 3) since the curriculum enrichment is competence and professional needs, in terms of the learning activities and the learning results, the supervision and control should be integrally considered. The implication of the curriculum enrichment in madrasah is the improvement of the competence in the science and technology without ignoring iman (faith), Islam and ihsan (good deed).
\end{abstract}

Keywords: curriculum, enrichment, reconstruction

\section{Introduction}

Education principally is any efforts to fulfill various demands for the quality of the young generation in terms of the children's cultural, social and developmental demands. The cultural demand in education is intended to make Indonesian people able to improve the human degree of the nation. The social demand deals with any demand for human resources, namely each human being should be useful for his/her own life or for the wide society, because each member of the society that is not productive and is notable to make his/her own living principally raises social burdens. Dealing with the students' developmental demand, each student principally needs developing their basic potentials including thinking potential, creativity, and social potentials so that they may build their emotional maturity, attitudes and identity human beings with good education, science and knowledge.

In the efforts to fulfill the above-mentioned demands, the national education is expected to serve its functions, namely developing capabilities and forming characters and civilization of the nation in order the make the life of the state smart. Muhadjir (2006) states that the educational institution is expected to implement three functions of education: 1) keeping eternal human and divine values; 2) growing students' creativity, and 3) preparing productive workers, namely those who are capable of anticipating the future, so that education may characterize the work structure of the future, instead of adapting to the prediction of the economic demands.

Philosophically, the function of education is to develop students through mental and rational processes so that they possess noble values. Education should emphasize productivity and efficiency. Sociologically, education serves two main functions namely manifest and latent (Sonhadji, 2000). Manifest function in education is to teacher subjects specific for students such as reading, writing, arithmetic, and other academic skills. Meanwhile latent function is to teach skills and social attitudes, such as self-discipline, cooperation with others, obeying the law, and hard work to attain a goal. Both functions play a vital role in realizing the functional integration of the people and to maintain the existing social structure.

Economically, the function of education is to contribute to the economic growth through improving the existing 
labors' productivity, because the economic growth is not only determined by the capital investment, but also the labors with flexibility in mastering new skills to do new jobs, in line with the changes in the economic structure and work field.

Based on the descriptions above, it can be stated that education plays an important role in determining the future. Malik (1999) states that education possesses four significant potentials for the future: 1) education provides tested modes in implementing the people's changing values and emerging desires and also in producing new values. Therefore, education does not create the future but may reflect changing cultures and prepare better ways of life; 2) education has shown its high capability of accepting and implementing new alternatives, and 3) education is the best way the people can do to guide human development so that each child's mental experience may develop and it is necessary to promote some concentration on his psychological intellect and to use the prepared concept of the curriculum for learning activities.

The concept of the curriculum gives an emphasis on the concept as the reinforce of the knowledge to make students' learning experiences and the core of the curriculum material as knowledge that is free from political and economical influences or other interests. In organizing the curriculum, a subject-centered approach is adopted, covering the environmental needs, the broad core of the materials, needs and tasks, practical experiences, and measurable results. The teachers' role in the mode of the environmental needs is operational in nature for the process of transformation and conceptual learning (Joyce \& Weil, 2009).

Changes in the measurable core-material of the curriculum will not automatically happen, but they come from the results of researches and theoretical-practical bases in the field of life. The social construction of the curriculum takes into account of the elements of the curriculum materials in detail and various social elements, such as social problems and dilemma, a dilemma that should be reviewed in order to take steps in adapting the students' learning activities.

Planning and handling the model of the curriculum social reconstruction should be arranged in accordance with the environment, be objectively and practically done and based on the objectives of the learning activities. Adapting to the social problems is an objective encouragement on how to solve learning problems in general (Merriam, 1979). All students, without any exception, should have learning experiences to study learning problems and the teaching and learning parameters.

The actualization of the curriculum has changed from the traditional model into a different model and has widened into the core of knowledge practically that is very promising (Linda, 2008). The use of the changes in self-actualization is to grow and to relate the classroom situation to the practical life. According to Linda (2008) it is called an educational-connoisseurship concept. And to change into the concept, a soft way should be adopted, so that the curriculum organization is inclined into using a social-centered approach.

Considering the quality of education based on the alternative curriculum concept, some adaptation and changes of the learning curriculum materials as the institutional actualization would be resulted in. Klein (2003) raises a concept of the cognitive process, namely the institutional actualization is based on the continuous process and knowledge. This process is an effort to make academic development in order to widen the perspective.

The shift and expansion of knowledge may be made through some aspects: 1) natural perspective, that the nature will raise spirits and academic attitudes widely and may enrich science and technology and promote some awareness to fill and conserve it; 2) the continues process and enrichment of the knowledge cognitively are called scientific treasure, namely the enrichment of the curriculum materials oriented into science and technology, in order to grow human beings from the sides of wisdom and togetherness, and to emphasize the human values; and 3) enrichment of spiritual and divine insights, relating the human beings' emotion and knowledge on the divine teachings to groom the ideology of idealism, ideals, and of struggles. The process needs the perfected curriculum concept, meaning any thoughts of looking for and getting new values to face the future and being assumed to grow in our life.

The curriculum enrichment is an alternative sped to get quality and mastery-learning. Therefore, the curriculum materials should contain ideas about the content to be able to be more valuable in the future.

Klein's (2003) opinion of the educational curriculum enrichment includes some aspects: 1) taking ideas from the curriculum content to be formulated to become the learning materials and to give more values; 2) widening the perspective of the curriculum materials to become the model of life in the teaching-learning process; 3) making the curriculum materials of the education as a variety of integrated knowledge in order to realize the results of mastery learning; and 4) making new breakthroughs to produce learning excellence (Yuonma, 1985).

Fadjar (1999) insight on the knowledge competence includes: 1) being free and active in decision makings; 2) 
making efforts to interpreter and analyze the situation and experience; 3) possessing knowledge to have pre-planned characters and grills as the main priority; 4) having an integrated relation to the analysis of objectives, competence of characters and products, and 5) making a curriculum enrichment centered on the struggle with maximal efforts. The curriculum enrichment is intended to attain dimensional competence (Polanyi, 1962) in rational and sophisticated learning to reach the main goal in learning namely: 1) moral-dimension, related to the learning competence and model the may produce special values, and 2) intellectual dimension, ideas that are related to competence and development of the students and that are adapted to the whole students' needs.

The educational curriculum materials are related to the curriculum materials and to the students' individual social development. McNiel (1990) support the statement due to some benefits of the curriculum namely: first, discovery, learning is to discover in the social process and in the learning tasks; second, teachable moment, bringing concepts of various types of experiences to facilitate students 'understanding and mastery.

\section{Literature Review}

The educational curriculum enrichment is influenced by a concept of technology (Joyce \& Weil, 2009) in order to design an adequate curriculum in advancing the learning process. The main focus and objectives of the teaching-learning activities are based on the cognitive concept, where a process serves as the realization of self-actualization and the educational implementing institution as an integrated interrelationship.

The concept of the curriculum enrichment is centered on the curriculum substance as wide and strengthening views for students, so that planning is adapted to the vision of education. The substance of the curriculum materials in the application is inseparable from the curriculum technology.

The substantive enrichments according to Robert (2009) are based on some aspects: 1) raising ideas; 2) formulizing concepts; 3) giving perspectives of competence and results and 4) producing complement and integrated knowledge.

This substantive enrichment of the curriculum core is intended to attain excellencies or more values, where a preparation is made to result in a concept of promising and inclusive learning and to out ideas of the curriculum prevailed in the past and to study the present content to be able to answer and face the future challenges.

Mastery and excellence learning as academic thinking processes is based on clear ideas to be able to build the social life and to show students' self-identity. Robert (2009) suggests that students' knowledge be improved in order to make them really posses the knowledge. And the teachers themselves should also try to reach their own academic achievement by continuously growing and improving their knowledge. In the academic field, therefore, a "curriculum incorporated should be adopted in developing the curriculum.

John (1990) programmed educational curriculum enrichment by changing the curriculum arrangement. There are many changes made to reconstruct schools as centers for research and reflection, instead of for testing traditions. To improve the school planning and the mastery of the concerned parties (parents, teachers, administrative staffs, and secondary school students) and also to decide some important problems such as budgets, curriculum objectives, school dynamics or development, the teachers are hired based on the school needs and ethos. And ascertain that students may study well at schools, some considerations are made, among others how to allocate time, so make use of the existing spaces/rooms, to clarify students, to classify problems, to adapt different types of intelligences, and to study learning models (Klein, 2003).

There are two steps to make the educational curriculum enrichment in some levels of objectives and school programs in each area. First, top-down, where the enrichment is done in line with the technology advancement and the changes are made in learning activities in accordance with the present development. The changes in curriculum are parts of school technology, and are related to the evaluation program, information technology and mastery learning. Teachers' perspective of the educational curriculum changes is a necessity to produce competences and learning innovations. Second, research and development model, where the curriculum arrangement is focused on elements of management, from planning, organization, application and evaluation. Any changes in education institutionally to produce the expected curriculum are considered to be effective since the changes are in line with the stake holders' intention.

The use of this model may construct forms of curriculum as the realization of the roles the teachers, schools, and trainers make, and may continue to the other matters, and it gives what is called as a "multiple effect" (Elliot, 1983). The developers consisted of some elements such as innovators, head master, motivators, and assistants when the changes are in progress. When they were making the curriculum in the training center, the headmaster supported them by looking for ways to widen what were the teachers done in the class by giving ideas on the 
teachers may organize and manage the class of the curriculum makers. The headmaster created a mental impression of should be fulfilled by the students and how they perceived various kinds of disciplines, including the arrangement of the attainment of the students by measuring the consistencies based on the intention the changers wanted to make. The staffs reviewed the expectation of the attainment and offered suggestions for modifications the headmaster should make in his operational activities.

The teachers, the students, the board members, and the administrators play their roles in analyzing the policy of the curriculum of which also delineate their political base and the changes of professional tool at the national, provincial and other levels to keep values. Karen (1988) states that in implementing the curriculum, three concepts related to the results of the teachers' analysis and the learning technology, exist namely the aim of the curriculum, the objectives of the curriculum" and the objectives of learning. The scripts are separated from the specific relevance from the local or school system. The aim of the curriculum is defined as the general programmatic expectations without any criteria of attainment or mastery, therefore it can be set. The objectives of the curriculum come from the aims of the curriculum. The aim or the objectives of the curriculum are the sources of the school philosophy and the statement of the objectives (Susan, 1983).

\section{Method}

It is qualitative and naturalistic in nature with a case-study approach, trying to obtain holistic research results with deep-insights. The data, either emic or etic, were obtained from MAN I Unggulan Tulungagung by taking ideas of the educational curriculum enrichment (Griffin, 1987).

The research was located in MAN I Unggulan Tulungagung, through the observation of the curriculum enrichment related to the madrasah unggulan as an important target and the centre for the study called the "extreme case" (Merriam, 2001) as the meeting points of a research pattern of a case-study. Then, in the research gradual steps were also taken namely: 1) classifying symptoms in detail; 2) examining proper media for observation; 3) categorizing the functions of the symptoms; 4) making planning of sampling to have a proper target; 5) determining codes to be consistently applied; and 6) making data analysis (Pattrick, 1995). And the procedures of data collection were observations, interviews, coding, naming, data management and interpretation.

In this present research, a qualitative design using a linear combination of data from files, units, or from the organization of the research location was employed. Merriam (2001) suggests that researchers always relate facts and the facts are always processed during the research. They always manage the data into folders of indexes, files, and then they are analyzed manually. Then the data organization is accompanied by analyzing the data continuously to obtain insights and interpretation as a whole.

Technically, Croswell (1998) proposes a spiral data analysis by making the following steps: 1) preparation: managing the collected data into files, units, or organization; 2) reading and signing, and reflecting by crosschecking with questions during interviews; 3) describing and interpreting the results of the cross-checking of the questions as symbolized in events, stages and comparisons; 4) interpreting the results of the descriptions, then they are represented visually and 5) determining the propositions of the results of the case-study either from the files, units, and the organization.

\section{Result and Discussion}

\subsection{Background of the Curriculum Enrichment of MAN I Unggulan Tulungagung}

This research saw some phases in the process of changes in the Madrasah as a mobilization and identified some needs and demands for continuing the changes. Curriculum enrichment is a system of planning learning activities in the madrasah systematically and measurably. The implementation involved academic experiences, tried to apply ideas and made reformation in the practice. Curriculum as a learning system contains a narrative of the documents designed, arranged and determined by the implementing institution of education as expressed in the vision and missions.

Curriculum enrichment as a routine sustainable process of imitation and combination, refers to changes as a part of educational system, and thinks that students naturally have characters and thinking potentials, do something to have their life experiences.

\subsection{Managing the Curriculum Enrichment of MAN I Unggulan Tulungagung}

\subsubsection{Planning the Curriculum Enrichment}

The findings showed that the teaching-learning activities of Arabic and English were managed by the language unit provided with two language laboratories, of which the head was academically structured. Moreover the 
ceasing-learning activities were done out of the regular schedule. To improve students' motivation in speaking the languages in their daily lives, the emphasis was given on conversation and a native speaker was invited. Moreover, to promote and to reinforce the activities of speaking the languages, the language unit held among others speech contests among madrasah, and the curriculum enrichment in languages was made in cooperation with the language unit of IAIN Tulungagung. The theme of planning the curriculum enrichment of MAN I Unggulan Tulungagung was based on the 2004 journal where from the observations made, an addition of time allotment was made on the basis of students' needs

\subsubsection{Organizing the Curriculum Enrichment}

In MAN I Unggulan Tulungagung, units supporting the teaching-learning process were established. Each unit had an authority to make any program reinforcing the learning activities, including the teachers. The units applied a motivate learning together in education and trainings activities referring to the productive curriculum enrichment and the units should also be responsible for the implementation of the education and training. The curriculum enrichment in MAN I Unggulan Tulungagung was organized in an integrated fashion among the units and the madrasah education. The implementation was successful in teaching the students to have creative thinking in the future. The curriculum enrichment made in the units was extra-curricular activities institutionally, but the materials are the continuation of the core ones.

\subsubsection{Controlling the Curriculum Enrichment}

The implementation of the curriculum enrichment in MAN I Unggulan Tulungagung involved the units existing in the madrasah (language unit, information technique and study) and the units should describe the implementation innovatively. In the curriculum enrichment, meetings were held to decide relevant materials given, and to make innovative development and implementation in order to have satisfactory results in the evaluation.

\section{Discussion}

In general, the attainment of the purpose of the curriculum in terms of the types of curriculum was divided into seven aspects. The seven aspects according to Olivia (1992) are as follows: 1) it is based on a learning skill, including completion or mastery of the curriculum; 2) an educational curriculum is intended to get children's expertise and growth; 3 ) competence and expertise in the curriculum materials in the educational curriculum is really needed in line with the schools' needs, especially madrasah; 4) competence in knowledge and at the madrasah level is intended to get maturity; 5) knowledge and academic competence are included in the educational curriculum materials to support the discipline related to the program of madrasah; 6) dealing with the curriculum materials, enrichment is made to improve and to deepen the knowledge to solve learning problems in madrasah and 7) the curriculum materials are deepened and widened based on time and opportunities to reach the aim of education and the cultural needs.

Then Joni (2000) suggests that the curriculum expansion and deepening ay be made through five types of curriculum and their levels namely: 1) ideal; 2) formal; 3) instructional; 4) operational, and 5) experiential curriculums.

Dealing with the function of this Islamic education, Furchan (2005) propose that the functions are as follows: 1) to develop students' potentials maximally and their interactions with their surrounding demands and needs without neglecting values and traditions that have been rooted in the society and have been relevant to be preserved; 2) to grow God and Human values in the context of the existing science and technology development and social changes; 3 ) to grow students' sustainable creativity; 4) to enrich the field of human culture, and divine and human values, and 5) to prepare students to have life competence and to be able and to be brave to face life challenges in line with the present time challenges perceived and with the Islamic spirits.

In order to be able to realize the functions, the curriculum enrichment is made. The curriculum enrichment in madrasah may make students to: 1) have knowledge and skills; 2) to be able to do tasks and duties in line with the knowledge possessed; 3 ) to be able to find their identity as what and whom he is, and 4) be able to cooperate with others and to do something useful for others.

On the basis of thr sub theme above, a hypothesis is proposed: the application of the curriculum enrichment in MAN I Unggulan Tulungagung is influenced by the thoughts of the Board of the Foundation. The curriculum enrichment in MAN I Unggulan have positive and significant impacts on the curriculum given to the students. Therefore, deepening and expanding the curriculum materials will raise some changes.

The planning of the curriculum enrichment in madrasah, either in the types of correlation, of automatic, and of activity in the core curriculum internally benefits for MAN I Unggulan Tulungagung as the implementer. The 
benefits are that: 1) the curriculum enrichment in the madrasah supports one another and is relevant; 2) the teachers' discipline is better; 3) the social-religious and linguistic activities get better; 4) Ma'hadiyah cultures characterize students' learning and praying activities, and 5) communication using Arabic and English is made among students and students and also among students and teachers and the communication is controlled by qismu al lughoh.

The organization and the direction of the curriculum enrichment in MAN I Unggulan Tulungagung are key of the successful education in madrasah using the model of widening and expanding curriculum materials adapted to students needs and done with an accountable mechanism. So that, it is necessary to formulate the success of the madrasah curriculum by paying attention to the following aspects: 1) decentralization of madrasah; 2) reformation in budget; 3) development of technology, information and communication, and 4) widening and expanding the curriculum materials in line with the students' needs for mastery learning.

The control of the curriculum enrichment in MAN I Unggulan Tulungagung was made by either internal or external monitoring or evaluations. This may improve the effectiveness and efficiency in managing the curriculum enrichment. As a result, the planners should understand the attainment of the curriculum enrichment. Therefore, the control serves to evaluate the implementation or the application with the determined standard. The results of the monitoring will show whether what has been planned may be reached or not. If it is not reach, improvement should be made

\section{Conclusion}

The curriculum enrichment in MAN I Unggulan Tulungagung is influenced by teaching-learning activities and the community of madrasah in the society in the beginning of the curriculum arrangement. The decision to make such a curriculum enrichment is related to the values of madrasah, oriented to; 1) a scientific study of Islam and technology as to make the outputs of madrasah to face their future; 2) the study of Islam as the characters and way of life; 3 ) the study of Islam as the benchmark to act as expressed in the models of goodness; 4) productive learning is the realization of the principles of syari'ah islamiah. Madrasah face a global competition and it is necessary to make some curriculum enrichment to improve the teaching-learning activities systematically and normatively. Managerially it may be said that the curriculum enrichment in MAN I Unggulan Tulungagung is made in an integral way with the units using normative and accountable principles.

The planning of the curriculum enrichment in madrasah involves practitioners and academicians to produce a curriculum relevant with the cultural condition and the advancement of the science and technology. The role of the stakeholders is very important as the party that accommodates the madrasah and people's needs, in order to make madrasah and the people productive in facing changes and the development of education through institutional innovations of madrasah. Institutional assistance and supervision of madrasah really help the smoothness of the application $f$ the curriculum enrichment and a model of direct evaluation by the institutional units may improve learning effectiveness and mastery.

The implementation of the management of the curriculum enrichment in madrasah involved elements and teams of practitioners or academicians as the consultants. And the implication of the demands to madrasah is on the image. The positive impact from the observations and the use of students on the curriculum materials delimited by the management of the curriculum enrichment in madrasah is that there is an appreciation to the learning activities as an academic image.

\section{References}

Eliot, W. K. (1983). Threat and Craft of Teacher Educational Research. NH. Heneman.

Fadjar, M. (1999). Reorientasi Pendidikan Islam. Jakarta: Fajar Dunia.

Furchan, A. et al. (2005). Perkembangan Kurikulum Berbasis Kompetensi di PTAI. Yogyakarta; Pustaka Pelajar.

Grifin, G. A. (1987). Leadership for Improvement Curriculum. Chichago: Pearbook Press.

John, D. M. (1990). Curriculum is a Comprehensive Introduction. University of California, Los Angels.

Joni, T. R. (2000). Memicu perbaikan pendidikan melalui kurikulum dalam rangka pikir desentralisasi antara content transmission dan pembelajaran yang mendidik. Yogyakarta: Kanisius

Joyce, \& Weil. (2009). Qualitative Inquiry and Research Design. London: Sage Publications.

Karen, S., \& Dentley, L. R. A. (1988). Knowledge Use and School Improvement in Curriculum Inquiry. Urbana.

Klein, F. (2003). Altrnative Curriculum Conception and Design. Boston, New York.

Linda, S. T. (2008). The Moral and Academic Curriculum in Higher School Education. California University 
Pacific Stokton.

Merriam, S. B. (2001). Qualitatif Research and Case Study Application in Education: Revised and Expanded from case study research in education. San Francisco: Jossey-Bass.

Muhadjir. (2006). Ilmu Pendidikan dan Perubahan Sosial Teori Pendidikan Pelaku Foral Kreatif. Yogyakarta: Rake Sarasin.

Oliva, P. F. (1992). Developing The Curriculum. New York: Hatper Collins Publisher, Inc.

Patrick, S. (1995). Curriculum Development in Posmodern Era, USA. Critical Education Practice, VOL. I.

Robert, K, Y. (2009). Case Study Reseach Design and Method. California:Sage Publication.Inc

Sonhaji, A. (2000). Penerapan Total Quality Management dan ISO. Malang.

Sussan, F. H., \& Aum, L. (1993). Curriculum Inplementation in Fundamental Curriculum Resisian. ASCD, Manbook, Alexandria.

Yuonma, S. L. (1985). Naturalistic Inquiry. California: Sage Publication Inc.

\section{Copyrights}

Copyright for this article is retained by the author(s), with first publication rights granted to the journal.

This is an open-access article distributed under the terms and conditions of the Creative Commons Attribution license (http://creativecommons.org/licenses/by/3.0/). 